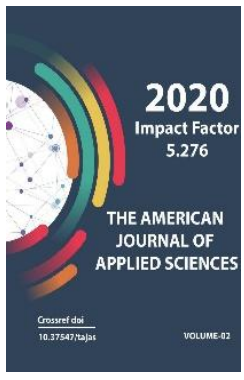

Journal Website: http://usajournalshub.c om/index,php/tajas

Copyright: Original content from this work may be used under the terms of the creative commons attributes 4.0 licence.

\section{Analysis Of Natural Field Research In The Assessment Of Processes In The Foothills}

\author{
A.M.Arifjanov \\ Dsc, Professor, Tashkent Institute Of Irrigation And Agricultural Mechanization Engineers, \\ Tashkent, Uzbekistan \\ Z.lbragimova \\ Assistant, Tashkent Institute Of Irrigation And Agricultural Mechanization Engineers, \\ Tashkent, Uzbekistan \\ I.G'Axmedov \\ Phd, Docent, Namangan Engineering And Construction Institute, Namangan, Uzbekistan
}

\title{
ABSTRACT
}

This article analyzes the factors influencing the occurrence of the deformation process in the channels based on the information obtained in the natural field conditions. The processes taking place in the Sokhsay river basin in the Sokh river basin were analyzed. During the research: The morphometry, flow rate and turbidity of the Sokhsay river were studied.

\section{KEYWORDS}

Bank, deformation, river, sediment, turbidity, waterworks, stream, particle.

\section{INTRODUCTION}

One of the important issues is the assessment of processes in the river basin and the improvement of computational methods and technologies for the prediction of river deformation. In this regard, in the assessment of the processes of the river, special attention is paid to scientific research on the prevention of turbidity of hydraulic structures in the riverbed and canal $[1,2,3]$. 
One of the peculiarities of pre-mountain rivers is that the slope of the riverbed is high.

The effect of sediments in the foothills on the change of hydraulic elements of the structure has been studied for many years $[4,5,6,7]$. One of the main influencing factors in the assessment of river basin processes is river sediments. However, the problems of analyzing the mechanical composition of sediments and determining the characteristics of sediments have not been fully resolved. Research will be needed to study the mechanical composition of sediments in premountain rivers and to assess their impact on river formation. It is known that river sediments consist of suspended and deep sediments, and natural field studies have been conducted to study the amount and composition of sediments in the Sokhsoy River, which receives water from the Sarikurgan hydroelectric power station.

\section{MATERIALS AND METHODS}

Several pickets were selected to determine the amount of sediment in the Sokhsoy riverbed, and the dynamics of the riverbed was studied at these pickets (Figure 1).

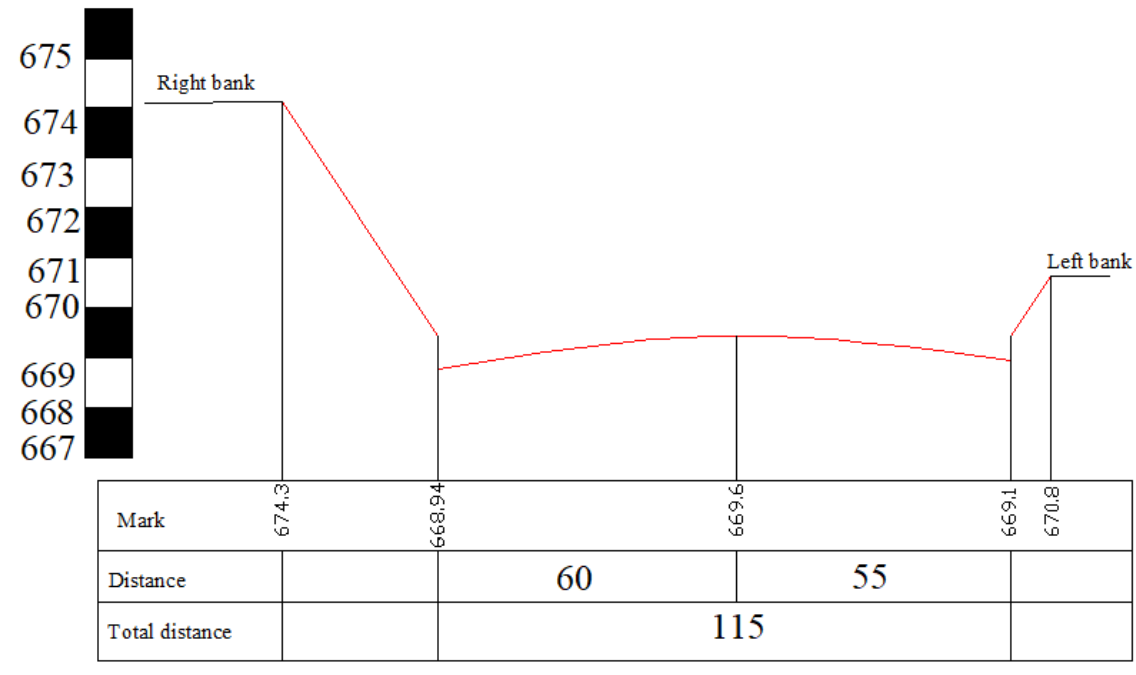

Figure 1. Process in Sokhsoy river PK-12

The studies studied the amount of suspended and bottom sediments, their fractional composition and their variation along the length of the stream. In the study, information was obtained on the distribution of sediments by pickets (Figure 2 ).

Soxsay valley was divided into several storks. The parameters of each storso were analyzed during the year. 


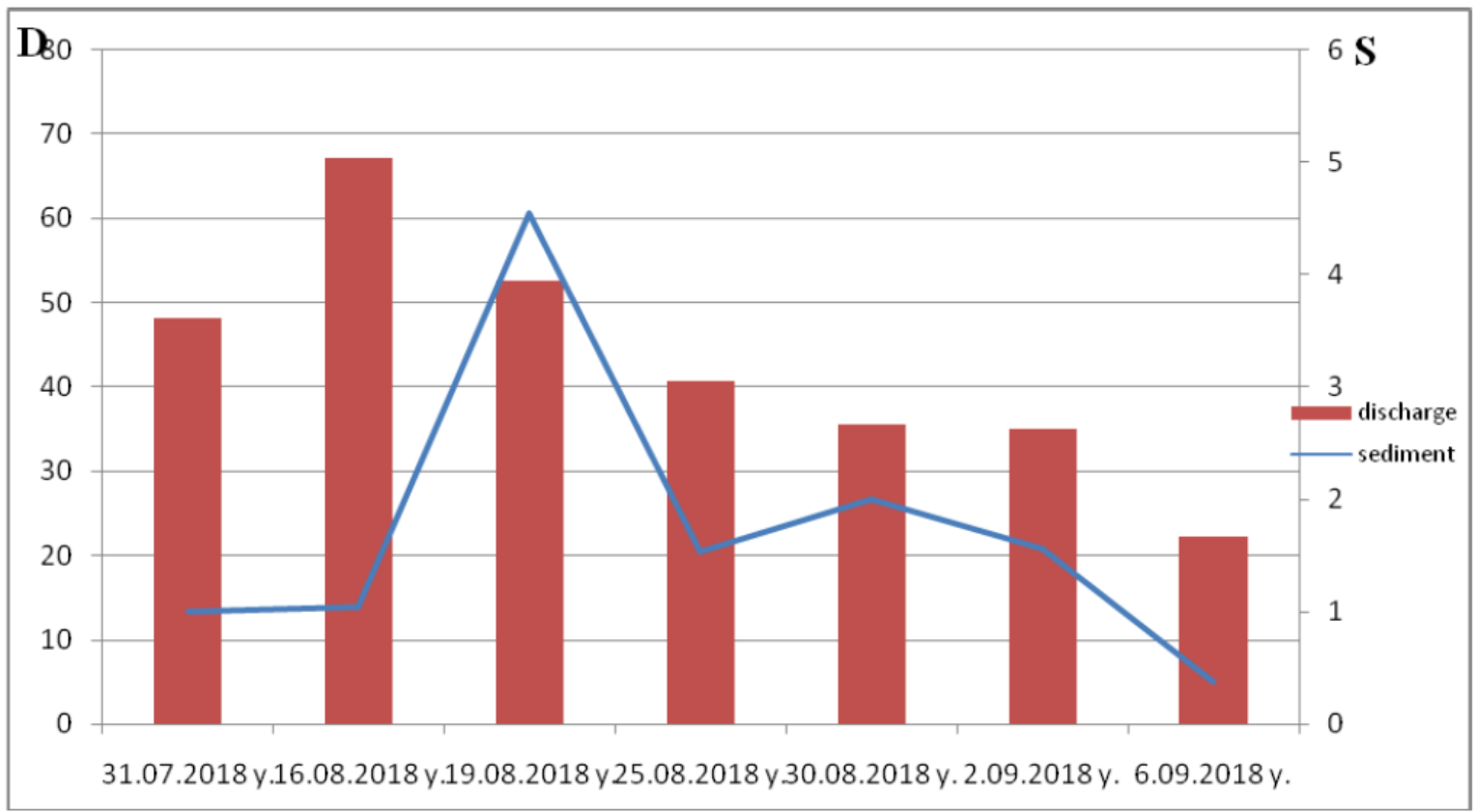

Figure 2 . Schedule of dependence of sediment flow with water discharge

According to the results of the research, the fractional composition of suspended sediments for pickets in the Sokhsay river is given in Table 1. Based on the analysis, it can be noted that the main part consists of particles with a diameter of 0.1-0.05 $\mathrm{mm}$ and $0.05-0.01 \mathrm{~mm}$, their total share is $68.9 \%$ and $27.6 \%$ (Table 1). 
Table 1. Fractional composition of sedimentary particles in the Sokhkoy valley

\begin{tabular}{|c|c|c|c|c|c|c|}
\hline \multirow[b]{2}{*}{ № } & \multirow{2}{*}{$\begin{array}{l}\text { Sampling } \\
\text { point }\end{array}$} & \multicolumn{5}{|c|}{ Sediment diameter $(\mathrm{mm})$, in\% } \\
\hline & & $\begin{array}{l}1,0-0,5 \\
\mathrm{~mm}\end{array}$ & $\begin{array}{c}0,5- \\
0,25 \mathrm{~mm}\end{array}$ & $\begin{array}{l}0,25- \\
0,1 \mathrm{~mm}\end{array}$ & $\begin{array}{c}0,1- \\
0,05 m m\end{array}$ & $\begin{array}{c}\text { 0,05- } \\
0,01 \mathrm{~mm}\end{array}$ \\
\hline ПК-12 & $\begin{array}{l}\text { The beginning } \\
\text { of the Sokhsoy }\end{array}$ & - & 4,6 & 17,64 & 62,95 & 4,81 \\
\hline ПК-62 & $\begin{array}{l}\text { The middle } \\
\text { part of } \\
\text { Sokhsoy }\end{array}$ & & 2,52 & 16 & 71,39 & 10,09 \\
\hline ПК-92 & $\begin{array}{l}\text { Сўхсой ўзан } \\
\text { охирги қисми }\end{array}$ & & & 7,4 & 32,39 & 59,61 \\
\hline
\end{tabular}

\section{RESULT AND DISCUSSION}

According to the analysis of the fractional composition of river sediments, in PK-12 0.5$0.25 \mathrm{~mm}$ diameter particles were 4.6\%, 0.25-0.1 $\mathrm{mm}$ diameter particles were $17.64 \%$, $0.1-$ $0.05 \mathrm{~mm}$ diameter particles were 62.95\%, 0.05$0.01 \mathrm{~mm}$ diameter particles were $4.81 \%$, In PK$62,0.5-0.25 \mathrm{~mm}$ diameter particles are $2.52 \%$, 0.25-0.1 mm diameter particles are 16\%, 0.1$0.05 \mathrm{~mm}$ diameter particles are $71.39 \%$, 0.05$0.0 \mathrm{~mm}$ diameter particles are $10.09 \%$, the composition of sediment at the end picket of the Sokhsoy river the fraction varies as follows: in PK-92, particles with a diameter of 0.25-0.1 mm account for 7.4\%, particles with a diameter of $0.1-0.05 \mathrm{~mm}$ account for $32.39 \%$, and particles with a diameter of $0.05-0.01 \mathrm{~mm}$ account for $59.61 \%$. Although the composition of sediments on the pickets is variable, the main part of them consists of sediments of 0.1 and $0.05 \mathrm{~mm}$ (Fig. 3). 


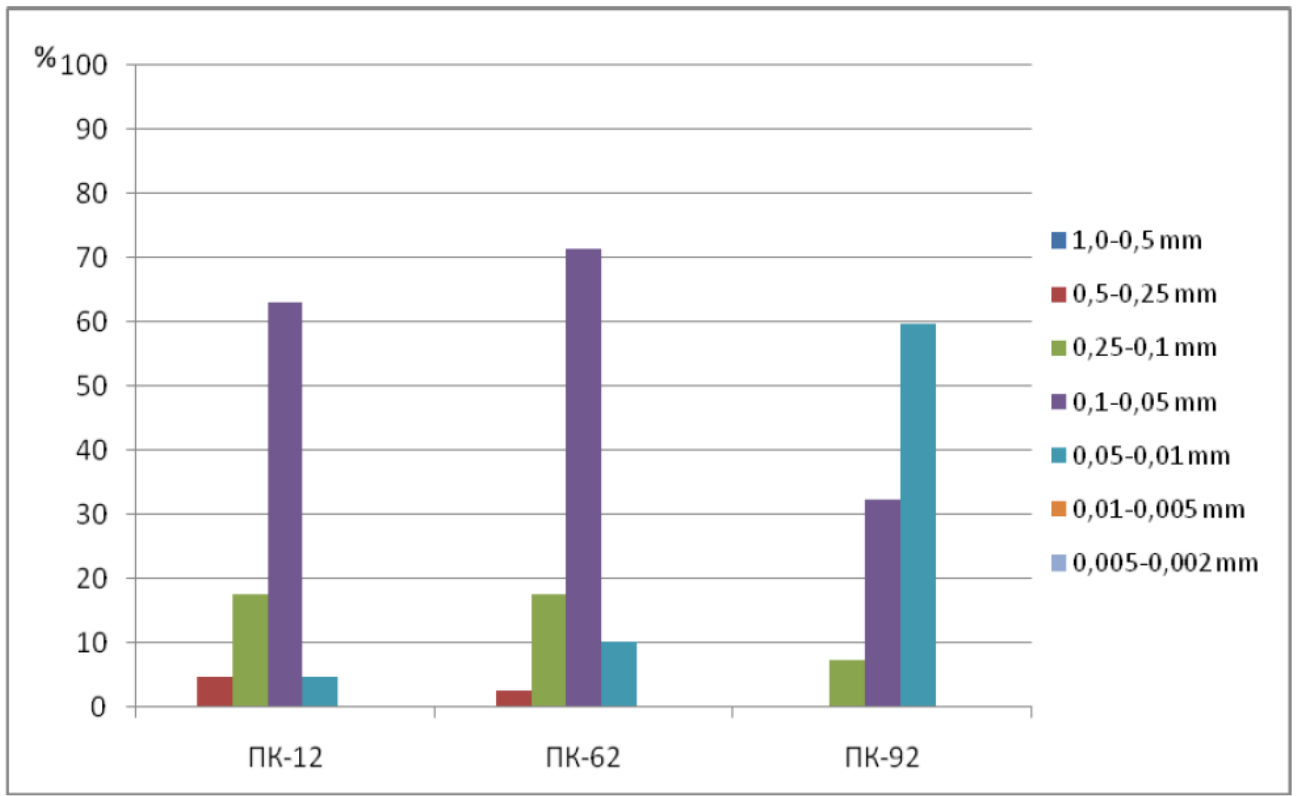

Figure 3. The fractional structure of the sediments in the Sokhsoy bed by the PCs

\section{CONCLUSION}

It is clear from the above analysis that the complexity of the processes taking place in the river is explained by taking into account many factors. Sediment analysis suggests that sand particles are flowing into the lower part of the Sokhsoy River, which has a negative impact on the operation of the hydropower plant and there is a problem of additional work at the hydropower plant.

It is necessary to change the hydraulic parameters of the Sokhsoy river, so that the sediments coming with a certain amount of flow can be trapped in the river it self.

\section{REFERENCES}

1. Arifjanov A.M., Fathulloev A.M. Dinamika vzvesenesushchego potoka $v$ ruslah. [Dynamics of a suspended flow in the channels]. Fan. Tashkent, 2014. 124 p. (In Russian)
2. Arifjanov AM, Fatkhullaev AM, Samiev LN, Ozandagi Jarayonlar va daryo cho'kindilari. [Processes in Uzgen and river sediments]. Tashkent, 2017. Monograph. The light of the publisher, 191p. (In Uzbek)

3. Arifjanov A.M. Metody raschota raspredeleniya chastits nanosov $\mathrm{v}$ ruslakh peremennogo secheniya[Methods for calculating the distribution of particles of sediment in the channels of variable cross-section]. Hydrotechnical Construction. Moscow, 2004. No4. Pp.50-54. (In Russian)

4. Arifjanov A. Raspredeleniye vzveshennykh nanosov $v$ statsionarnom [Distribution of suspended sediment in the stationary flow]. Water resources. Moscow, 2011. No2. Pp. 185-187. (In Russian)

5. Arifjanov A.M., Samiev L.N., Ahmedov I.G. Irrigatsionnoe zhnachenie rechnykh nanosov [The irrigational 
value of river sediments.] Moscow, Actual Problems of Natural Sciences, Noo6. (53) June 2013. Pp. 286-289. (In Russian)

6. Latipov K.Sh., Arifjanov A.M. Voprosy dvizheniya vzvesenesushchego potoka $v$ ruslah [Questions of motion of suspended flow in the channels] Tashkent: Mehnat, 1994. 110p. (In Russian)

7. Karaushev A.V. Teoriya i metody rascheta rechnykh nanosov [Theory and methods for the calculation of river sediments]. Hydrometeoizdat. Leningrad, 1977. 444p. (In Russian)

8. Abalyants S.Kh. Ustoychivyye i perekhodnyye rezhimy $v$ iskusstvennykh ruslakh [Stable and transient modes in artificial channels]. Gidrometeoizdat. Leningrad. 1981. 245p. (In Russian) 